\title{
WORK MIGRATION OF THE LABOUR FORCE: PROBLEMS AND WAYS OF SOLVING EMIGRATION IN UKRAINE
}

\section{ТРУДОВА МІГРАЦІЯ РОБОЧОЇ СИЛИ: ПРОБЛЕМИ І ШЛЯХИ ВИРІШЕННЯ ЕМІГРАЦІЇ В УКРАЇНІ}

UDC 332.1

https://doi.org/10.32843/infrastruct43-14

\section{Nikitina Alina}

Candidate of Economic Sciences,

Associate Professor,

Senior Lecturer at Department of

International Economics and Management

of Foreign Economic Activity

Simon Kuznets Kharkiv National

University of Economics

Tskhovrebova Yelizaveta

Student

Simon Kuznets Kharkiv National

University of Economics

\begin{abstract}
In the result of scientific sources on deep analysis of the labour migration, the peculiarities of migration processes in modern Ukrainian society have been considered. Trends as well as economic, sociocultural and sociopsychological risks of external labour migration have been identified. $A$ detailed analysis of the current migration situation in the country on the essence and consequences of migration and the reasons for the migration activity of the Ukrainian citizens has been made. Various groups of factors determining migration of the population have been considered and distributed: pulling, attracting and pushing. The main factors, which contribute to migration, have been outlined. The appropriate effective governmental and non-governmental ways of improving the migration situation in Ukraine have been suggested. The main effects of migration policies in terms of their impact on the labour market have been reviewed. The development potential of manpower immigration has been assessed and ways to attract the working population to Ukraine has been determined. The ways of solving the problem of emigration of able-bodied population from the Ukrainian society have been investigated and ways of improving the labour situation in Ukraine have beem suggested.

Key words: migration processes, trends, effects of migration policies, development potential of manpower immigration, labour situation in Ukraine.
\end{abstract}

В результате глубокого анализа научных источников о трудовой миграции были рассмотрены особенности миграционных прочессов в современном украинском обществе. Определены тенденции, а также экономические, социокультурные, социально-психологические риски внешней трудовой миграции. Был проведен тщательный анализ текущей миграционной ситуации в стране: сущность и последствия миграции, причины миграционной активности граждан Украины. Рассмотрены и распределены различные группы факторов, определяющие миграцию населения: удерживающие, притягивающие и выталкивающие. Выделены решающие фракторы, которые способствуют миграции. Были предложены соответствующие эсрорективные правительственные и неправительственные пути улучшения миграционной ситуации в Украине. Был проведен обзор основных последствий миграционной политики, с точки зрения ее воздействия на рынок труда. Был оченен потенциал развития иммиграции рабочей силы и пути привлечения трудоспособного населения в Украину. Были исследованы пути решения проблемы эмиграции трудоспособного населения из украинского общества и предложены пути улучшения трудовой ситуации в Украине.

Ключевые слова: миграционные процессы, тенденции, последствия миграционной политики, потенциал развития иммиграции рабочей силы, трудовая ситуация в Украине.

В результаті глибокого аналізу наукових джерел щодо трудової міграції були розглянуті особливості міграційних процесів в сучасному українському суспільстві. Визначено тенденції, а також економічні, соціокультурні, соціально-психологічні ризики зовнішньої трудової міграції. Був проведений ретельний аналіз поточної міграційної ситуації в країні: сутність та наслідки міграції, причини міграційної активності громадян України. Розглянуто і розподілені різні групи фракторів, що визначають міграцію населення: утримуючі, приваблюючі і відштовхуючі. Були запропоновані та впорядковані відповідні есрективні урядові та неурядові шляхи поліпшення стану міграційної ситуації в Україні. Було проведено огляд основних наслідків міграційної політики, з точки зору їі впливу на ринок праці. Був оцінений потенціал розвитку імміграції робочої сили і визначено порядок залучення працездатного населення в Україні. Були досліджені шляхи вирішення проблеми еміграції працездатного населення з українського суспільства і запропоновано шляхи покращення трудової ситуації в Україні. Актуальність дано теми полягає, перш за все, в важливості визначення наукових підходів щодо проведення міграційної політики на рівні держави. На сьогоднішній день проблема міграції трудових ресурсів є однією з наймастабніших проблем сучасної України. Упровадження недосконалої міграційної політики посилює ії негативні наслідки, до яких можна віднести: збільшення нелегальної міграції, неконструктивну економічну активність мігрантів, зростання господарського хаосу, посилення соціальної напруги, підвищення ризиків виникнення міжнаціональних, міжетнічних та міжконсресійних конфрліктів, відплив частини трудоспосібного населення. 3 метою підняття рівня ефективності міграційної політики України, були проведені спеціальні дослідження статистики міграції населення, зроблені відповідні висновки, розроблені пропозиції щодо необхідності удосконалення системи міграційної статистики та заходи щодо покращення міграційної ситуації в державі. Обгрунтовано, що з економічної точки зору міграція з України має як позитивні, так і негативні сторони. Запропоновано шляхи вирішення даних проблем. Зокрема були висвітлені фрактори, що впливають на міграційні процеси в Україні. Міграційні процеси мають суттєвий вплив на економіку кожної країни. Міграція трудового населення може бути дуже серйозною загрозою яка пояснюється підвищення безробіття, нестабільністю економічної та політичної ситуації, та іншими фракторами.

Ключові слова: міграційні процеси, тенденції, наслідки міграційної політики, потенціал розвитку імміграції робочої сили, трудова ситуація в Україні.

Introduction. Labour migration is an integral part of a socio-economic state of the country. Firstly, net immigration will lead to a growth in the size of the labour force and an increase in the productive capacity of the economy. Secondly, migrants fill important niches both in fast-growing and declining sectors of the economy. Thirdly, because immigrants are more likely to be young and working than native-born citizens, they provide a net benefit to government revenues. Working people pay income tax, but do not receive benefits, such as education, pensions. Young people are less likely to use health care services than old people. At the same time, immigration may have a variety of disadvantages to a country, which loses its workforce. Firstly, it leads to the outflow of the labour force, namely the working-age population. Secondly, 
workforce migration may trigger aggravated demographic crisis. Migration can have pros as well as cons, opportunities and drawbacks. It is vital to know how to manage a migration policy in order to get only benefits for the country. That is why it is necessary to investigate this problem.

Analysis of recent research and publications. Migration research problems have become relevant since the 1980s. An active study of labor migration in Ukraine began in the late 1990s of the 20th century. The prospects of migration in Ukraine were researched by the following domestic scientists: R. Bandura [1, p. 81-84], I. F. Hnybidenko [2, p. 11-16], I. S. Skorokhod and V. V. Bezukh [3, p. 27-32], O. M. Korzhyk [4, p. 278-282], O. A. Malynovska [5], V. G. Chebanov [6, p. 118] and others. They studied the processes of labour migration, including illegal migration, methods of investigation of migration processes in general, processes of urbanization and population mobility, the main directions and measures of state regulation of these processes. Nevertheless, the problem of labour migration has been studied rather poorly. The situation is changing over time, so that the issue of finding appropriate ways to improve the efficiency of migration policies in Ukraine needs to be further investigated.

In general, the economic and social consequences of emigration abroad have both positive and negative effects. External labour migration of the Ukrainian population has certain positives. The most important advantages of this phenomenon are the reduction tensions in the labour market, significant amounts of investment that the country receives through employment, increase of solvent demand due to income from labour [5, p. 18].

Labour migration plays a role of the low standard of living in Ukraine, which allows migrant workers to adapt to complex socio-economic conditions. In this context, displacement becomes a way of life for some Ukrainian citizens, at the same time causing demographic and economic losses [3, p. 27].

Aim of the article is to describe the indicators of emigration and immigration, analyze the positive and negative aspects of labour migration, reveal and systematize the problems that contribute to labour emigration from Ukraine; to identify and systematize the ways of improving migration policies in order to accelerate the social and economic development of the country.

Results. Nowadays in most countries, migration or labour processes have become a common fact. This usually has a negative impact on the economy of the countries, from which workers emigrate. Migration processes have a significant impact on the economy of each country. The point that we must emphasize is that the population of Ukraine is actively involved in world migration processes. In recent years, Ukraine has traditionally been on the list of countries, from which the largest number of people leave annually, as well as the list of countries where the largest number of migrants from other countries of the world come. Along with the economic situation in Ukraine, a significant factor of migration is the geographical position of the state at the intersection of major transport corridors, in particular, on the way from Europe to Asia, Russia, the Baltic States to the Middle East and Africa.

Having analyzed the scientific sources, it has been found that migration in the country is constantly increasing. The basis of migration flows in Ukraine is labour migration. It should be emphasized that labour migration becomes an effective means of employment, guaranteed income and self-realization for citizens, which generally contributes to the country's inclusion in the global labour market and the formation of a middle class and is a catalyst for integration into the global community. Annually, more than 5 million people leave Ukraine in order to work abroad. The attention should be payed to the fact that more and more people from villages and small cities decide to move abroad in search of work. The main features of workforce migration are the following:

- labour migration is more prevalent among men (65\%) than women (35\%);

- the level of participation of the rural population in labour migration is 2.9 times higher than in urban areas: about $6.3 \%$ of the economically active rural population work in foreign countries, while in cities only $2.2 \%$ of urban residents decide to emigrate abroad.

According to the National Academy of Sciences of Ukraine, $12 \%$ of the Ukrainian households are of at least one family member and have worked abroad. In 2017, the State Statistics Service of Ukraine published information on migration processes on the territory of Ukraine over the past eight years.

As we may see, official figures for emigration from Ukraine, according to the State Statistics Service, are quite small. Moreover, according to this statistic, less and less Ukrainians leave their motherland. It is obvious that these figures are underestimated due to illegal migrant workers who do not register in official migration institutions of Ukraine. In 2018, according to the research of the sociological group "Rating", which have interviewed 1200 respondents in all parts of the country, it has been claimed that the largest countries where the Ukrainians migrate are Russia (43\%), Poland (14\%), Italy (13\%) and the Czech Republic (12\%). Among other countries where labour migration flows are directed there are Spain (4.5\%), Germany (2\%), Hungary (2\%), Portugal and Belarus (1\% each) [7]. By the way, there are significant differences in the directions of external labour migration of men and women. Men are more likely to choose Ukrainian neighbouring countries: Poland, Russia, Belarus, the Czech Republic and so on. Women 


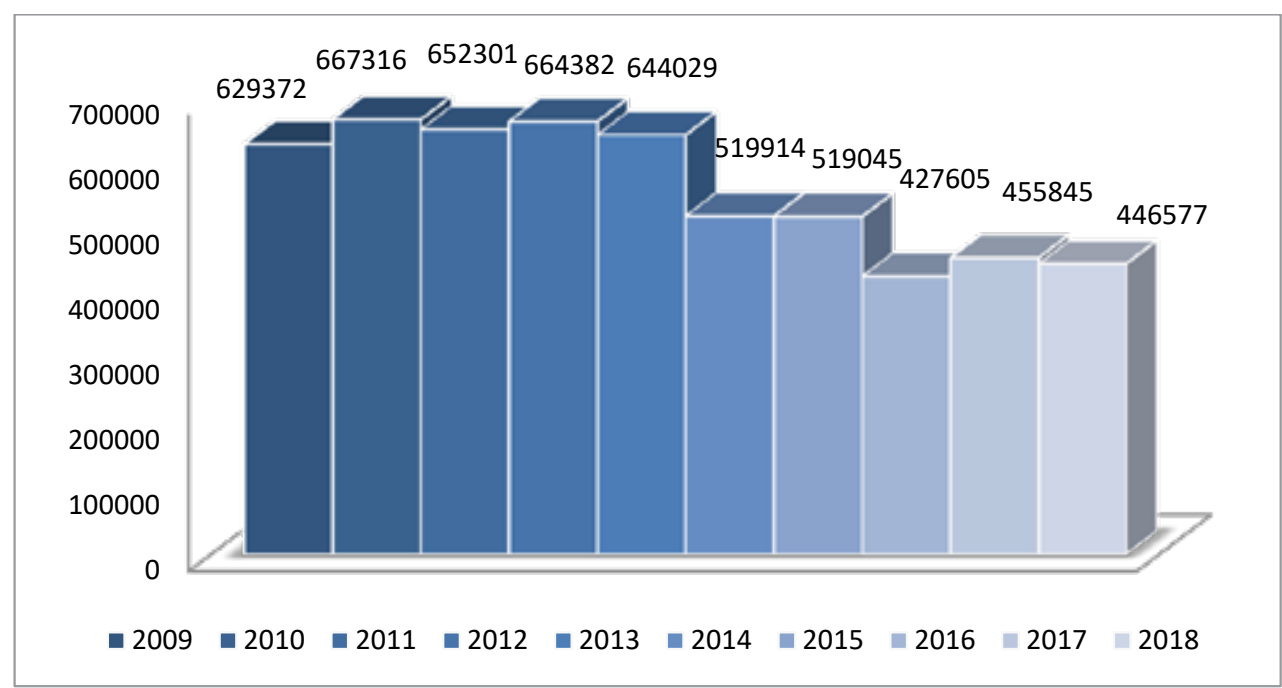

Figure 1. Migration movement of Ukrainians from 2009 till 2018

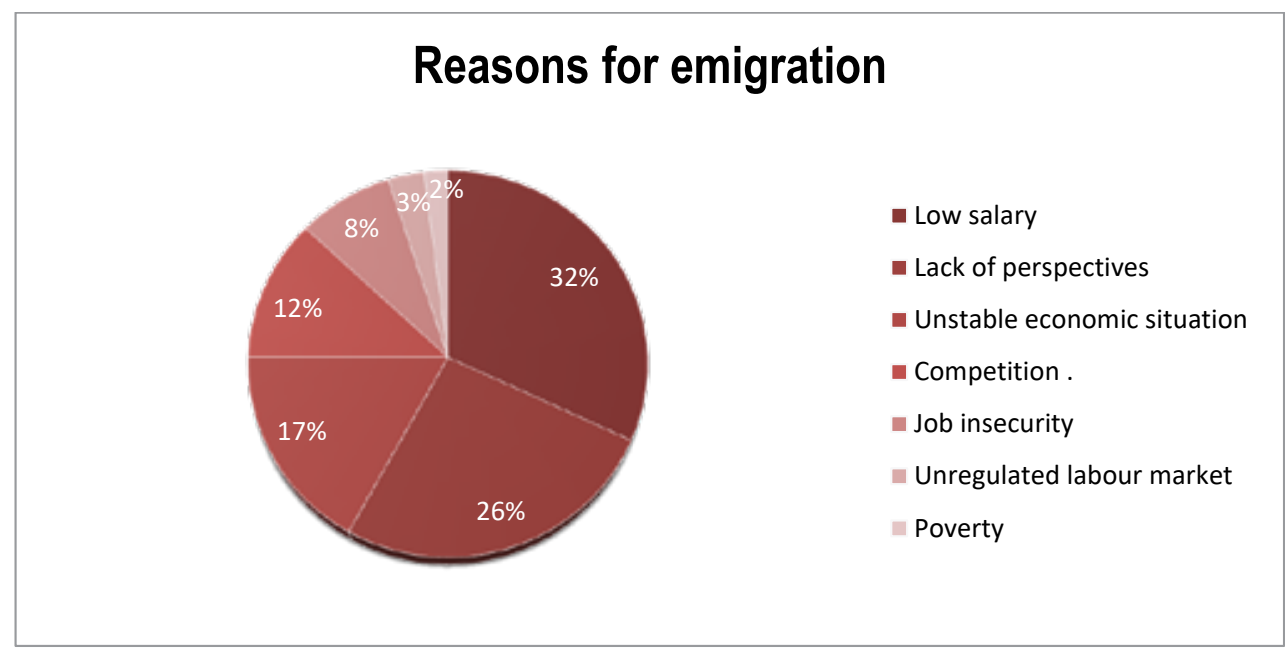

Figure 2. Reasons that lead to emigration from Ukraine

would definitely prefer farthest countries: Germany, the USA, Italy, Portugal, Finland, Spain.

After performing analysis of the researches, we have identified main reasons for labour emigration from Ukraine.

Reasons for emigration may differ. However, among main causes of labour migration there are:

- complex economic situation in the country. First of all, there are job insecurity, poverty, low real wages and instability of political and economic situation. At present, there are almost 2.5 million registered vacancies in Ukraine that will never be filled, due to the fact that $64 \%$ of them offer the minimum salary;

- there is a significant imbalance between the volume and structure of demand for young people's labour. Such imbalance exists also between the volume and structure of their supply. Young people who cannot withstand tough competition with older generations are forced to move abroad in order to find job on the labour market;
- lack of prospects to apply the creative and intellectual abilities. A huge number of people do not see the prospects in their home country at all. They are not happy to work in the same position for the rest of their lives. It is an undeniable fact that there are few good jobs with high earnings. That is why people, who are disappointed with the job market in Ukraine, decide to find work abroad [8].

As we may see from the graphic, wage differentials between Ukraine and other European countries remain large. Although, average monthly wages in Ukraine have recovered substantially from 192 USD in 2015 , their lowest point during the economic crisis, to 424 USD in 2020, this is only about a quarter of average wages in current destination countries such as Poland or the Czech Republic and less than one tenth of wages in western and northern countries in Europe. Wage differentials are likely to remain an incentive for migration for years to come. According to the Labour Market Situation infographics published 


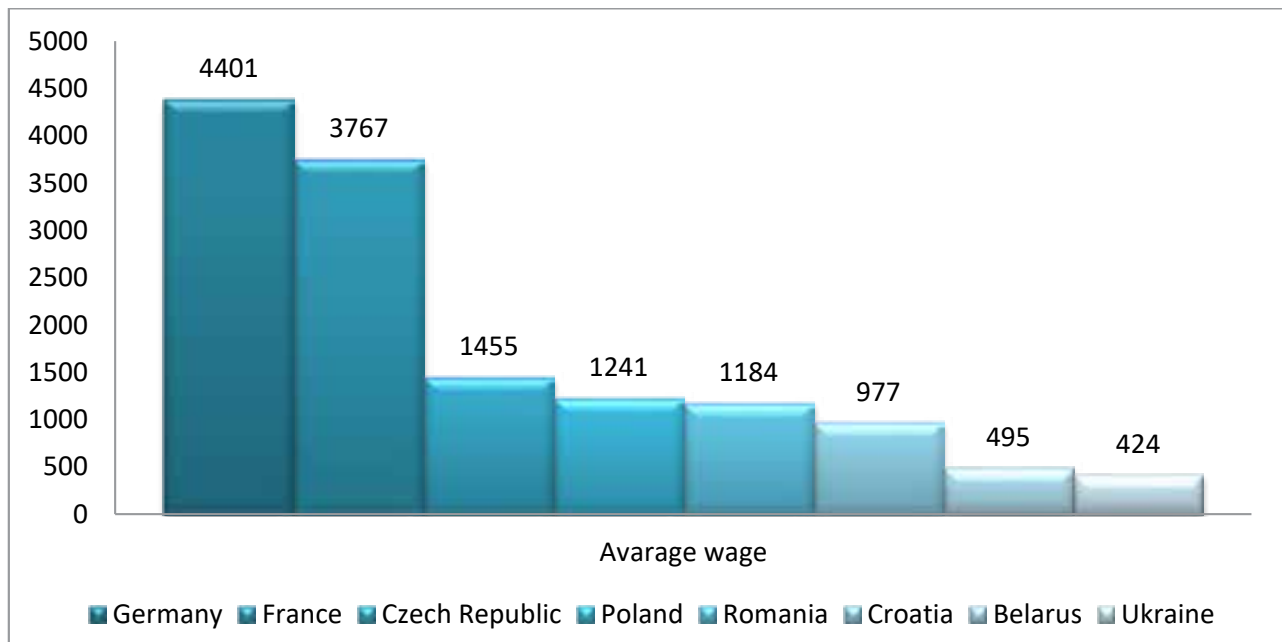

Figure 3. Average monthly wages in USD, 2020

by the State Employment Service (dated January 18, 2019), the average monthly wage of full-time construction workers in Ukraine is 9,205 UAH (341 USD). This is below the minimum wage in Montenegro (359 USD) [9].

The processes of international labour migration are multilevel and multi-vector. Their external economic effects are complex and multifaceted and have an ambiguous impact on the Ukrainian economy. As the experience of Ukraine shows, the neglect of migration processes predetermines the departure of the best part of the able-bodied population, the introduction of the country into the system of illegal labour migration. Labour migration, unemployment is a natural process of market relations. However, Ukraine has become one of the main labour donors for Western Europe, while the labour market in the country requires practitioners in almost all sectors of the economy. That is why it is so important to highlight the main advantages and disadvantages of labour migration. As a rule, migration of labour force abroad has negative consequences for Ukraine, namely:

- more slower pace of scientific and technological progress due to numerous intellectual emigration of the Ukrainian scientists abroad;

- cases of abuse and fraud on the part of citizens by private employment agencies are common;

- growing political and economic accusations against our state due to increasing illegal migration of the Ukrainian workers;

- low paid, hard job with harmful working conditions. Sometimes discrimination and exploitation by local employers.

The point that we must emphasize is that the lack of manpower is especially felt in the construction sector. It is accounted for a majority of migrant workers, due to the rising internal demand in the European countries. In recent years, labour migration has led to a labour force reduction and a decrease in the population of Ukraine. For example, from 2013 to 2016, the labour force aged 15 to 70 years in Ukraine dropped from almost 21 million down to 18 million persons, whereas the number of those employed and self-employed decreased by 2 million and 2.5 million persons, respectively. According to statistics from the Ptoukha Institute for Demography and Social Studies of the National Academy of Sciences of Ukraine, the number of able-bodied population of Ukraine aged 20 to 64 years will decrease by three million by 2030 [10].

On the other hand, labour migration clearly has had positive effects on Ukraine. When performing the analysis of the scientific sources, it has been found that workforce migration contributes to the development of the country's economy and has significant advantages such as:

- the comparatively high level of labour remuneration abroad encourages labour migration of population with a clear-cut seasonal character;

- it is also spurred on by the high demand for the blue-collar labour force, a good deal of which is unable to find a job in their home country;

- perception of the living standards in neighbouring countries helps migrants to develop corresponding standards and cultural values for themselves;

- it helps migrants to eliminate poverty and generally improve the economic security and living quality of their families.

It is quite clear that labour migration cannot be stopped. However it is possible to make it legal and circulate. The implementation of the strategy consists of four phases. These stages have been formulated on the basis of research, financial and banking experience with migrants. The implementation of these stages should take place in parallel, as millions of Ukrainians are already abroad, and many of them are already in the middle or end of the migration cycle. 

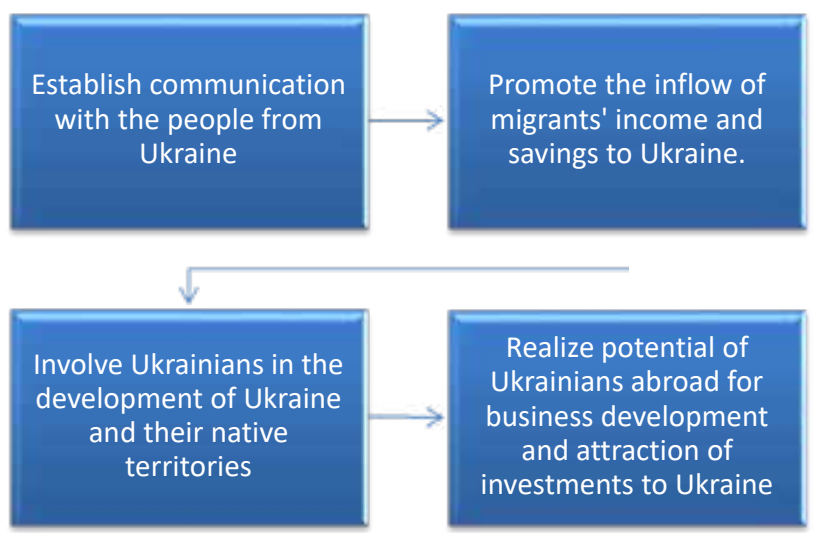

Figure 4. Consecutive steps to improve the migration situation in Ukraine

Firstly, Ukraine must know where the Ukrainians are in order to bring them home. The conditions of consular registration should be significantly simplified; this will help the Ukrainian authorities. It is necessary to understand the reason for their departure, to assess the skills of the person. Labour departments should be established in each embassy abroad to advise migrants on return programmes and support in their home country. Secondly, it is necessary to facilitate the flow of migrants' money to Ukraine. It is necessary to create programs of financial inclusion, information systems (sites, platforms, contact centre) about convenient and inexpensive transfer systems, programs to reduce the cost of transfers. It might be required to launch targeted banking, insurance, mortgage, pension and savings programs and services, which will create additional motivation for the transfer of funds of our migrants to Ukraine. Thirdly, we should persuade people to invest money in Ukraine. One of the mechanisms to attract development savings from migrants is the Diaspora Bonds infrastructure bond. It is important to identify the purposes, for which funds and the guarantees for their return are raised. For the most part, people are ready to invest in the construction of large-scale infrastructure projects. It is also vital to hold donor conferences at the regional level to raise funds for socially important infrastructure projects periodically. Such events are best held in regions with high emigration rates. The last point is to use migrants abroad in order to attract investors in Ukraine. It is extremely necessary to create programs for entrepreneurship development, launch of new business projects and development of business contacts. If a migrant in the homeland has created conditions for the emergence of valuable assets or existing business, he or she no longer thinks about whether he or she should return to the homeland or not. It is required to develop advisory training programs on the creation of small businesses among returning migrants. This will definitely lead to an increase in foreign investment in Ukraine. This is the path that Turkey, Israel, Portugal, South Korea and Ireland followed between 1960 and
1990. Firstly, our migrants invest in their country, in Ukraine, and then they "attract" foreign investors to increase the inflow of investments. It is our migrants worldwide, who guide foreign capital into the country. The government of Ukraine should study the experience of other countries, which also fight against migration, carefully. It is obvious, that some methods can have a positive impact on the migration process. That is why it is required to adopt them. By doing so, our country will be able to optimize migration processes and thus create the prerequisites for sustainable economic development in the future.

Conclusion. Labour migration is an essential part of the Ukrainian economy and is extremely important for its development. Labour migration clearly may have positive as well as negative effects on the development of the country. Although its effects so far have been mainly beneficial for migrants, their families, and the Ukrainian economy as a whole, this may change in the long run if emigration begins to hurt cost competitiveness, the investment climate, and public finances in Ukraine. One thing is clear: policy implications, for sure, are not trivial. We have discovered that government cannot fully stop and prevent its citizens from moving abroad freely. That is why it is extremely necessary to lead prudent migration policies. Statistical data is required to have up-to-date and comprehensive information on this important issue. By implementing comprehensive economic reforms now, Ukraine definitely has the opportunity to create sympathetic conditions for economic growth and social development. This, in return, will improve people's expectations for their lives in Ukraine compared to potential countries of destination. Whether labour migration will remain a positive factor for Ukraine and Ukrainians or whether it turns into a negative spiral of depopulation and slowing growth depends on the success of comprehensive policy reforms that need to be implemented as soon as possible. As for today, the country has enough sufficient resources to not only turn the migration of workers from Ukraine into positive consequences, but also to create favourable conditions for the flow of workers to Ukraine. According to the scientific researches we can claim, that labour migration will remain vital for Ukraine in the medium term - for individual citizens, for policy makers, and for the economy as a whole.

\section{REFERENCES:}

1. Bandura R. (2014) Sotialna robota z migrantamy [Social work with migrants]. Nova pedagogichna dumka, no. 1, pp. 81-84.

2. Gnybidenko I. F. (2002) Ukrayinski trudovi migranty [Ukrainian labor migrants]. Nashe slovo, no. 19, pp. 11-16.

3. Skoroxod I. S., Bezux V. V. (2009) Prychyny mihratsiinykh protsesiv $v$ Ukraini [Causes of migration processes in Ukraine]. Naukovyi visnyk Volynskoho natsionalnoho universytetu imeni Lesi Ukrainky, 
vol. mizhnarodni ekonomichni vidnosyny, no. 11, pp. 27-32.

4. Korzhyk O. M. (2007) Trudova migraciya v Ukrayini: socialno-ekonomichni aspekty ta naslidky [Labor migration in Ukraine: socio-economic aspects and consequences]. Naukovyi visnyk Volynskoho natsionalnoho universytetu imeni Lesi Ukrainky, no. 1, pp. 278-282.

5. Malynovska O. A. (2011) Sotsialno-ekonomichni ta etnokulturni naslidky mihratsii dlia Ukrainy: zb. materialiv nauk.-prakt. konf. [Socio-economic and Ethnocultural Impacts of Migration on Ukraine: Collection of Scientific and Practical Conferences]. P. 344.

6. Chebanov V. G. (2009) Zovnishnia trudova mihratsii naselennia Ukrainy [External labor migration of the population of Ukraine], p. 118.

7. Ukrainska mihratsiina statystyka [Ukraine Immigration Statistics]. https://www.macrotrends.net/countries/UKR/ukraine/immigration-statistics. (accessed 10 May 2020).

8. Mihratsiia v Ukraini: fakty ta tsyfry (2013) [Migration in Ukraine: Facts and Figures]. Vol. 2. http://iom.org.ua/sites/default/files/eng_ff_f.pdf. (accessed 10 May 2020).

9. Zarobitna plata v usomu sviti porivniano z Ukrainoiu [Wages worldwide in comparison with Ukraine]. https://tradingeconomics.com/country-list/wages. (accessed 10 May 2020).

10. Andreyev V., Borysov O., Klymenko K. Vplyv ukrainskoi mihratsii robochoi syly na rynky pratsi $v$ Ukraini ta Yes [The impact of Ukrainian labour migration on labour markets in Ukraine and the EU]. https://www.civic-synergy.org.ua/wp-content/uploads/ 2018/04/The-impact-of-Ukrainian-labour-migration-onlabour-markets-in-Ukraine-and-the-EU-a-Case-Studyof-Construction-Workers.pdf. (accessed 10 May 2020).

\section{БІБЛІОГРАФІЧНИЙ СПИСОК:}

1. Бандура Р. Соціальна робота 3 мігрантами. Нова педагогічна думка, 2014. № 1. С. 81-84.

2. Гнибіденко І. Ф. Українські трудові мігранти. Наше слово, 2002. № 19, С. 11-16.

3. Скороход І. С., Безух В. В. Причини міграційних процесів в Україні. Науковий вісник Волинського національного університету імені Лесі Українки Серія: міжнародні економічні відносини, 2009. № 11, C. 27-32.

4. Коржик О. М. Трудова міграція в Україні: соціально-економічні аспекти та наслідки. Науковий вісник Волинського державного університету імені Лесі Українки, 2007. № 1, С. 278-282.

5. Малиновська О. А. Соціально-економічні та етнокультурні наслідки міграції для України: зб. матеріалів наук.-практ. конф, 2011. 344 с.

6. Під ред. Чебанова В. Г. Зовнішня трудова міграції населення України, 2009. 118 с.

7. Українська міграційна статистика. https:// www.macrotrends.net/countries/UKR/ukraine/immigrationstatistics. (дата звернення: 10.05.2020).

8. Міграція в Україні: фракти та цифри. 2013, випуск 2. http://iom.org.ua/sites/default/files/eng_ff_f. pdf. (дата звернення: 10.05.2020).

9. Заробітна плата в усьому світі порівняно 3 Україною. https://tradingeconomics.com/country-list/ wages. (дата звернення: 10.05.2020).

10. Андреєв В., Борисов О., Кліменко К. Вплив української міграції робочої сили на ринки праці в Україні та ЄС https://www.civic-synergy.org.ua/wp-content/uploads/2018/04/The-impact-of-Ukrainian-labourmigration-on-labour-markets-in-Ukraine-and-the-EUa-Case-Study-of-Construction-Workers.pdf. (дата звернення: 10.05.2020). 